\title{
URBAN DIFFERENTIATION: PROBLEMS AND PROSPECTS
}

\author{
Dennis C. McElrath*
}

Cities are focal points for a great variety of America's ills. City people daily clog highways, befoul air, pollute water, challenge sewer systems, make streets hazardous and public spaces lethal. Their sick, indigent, deviants, and aged make demands; their slums spread; their race relations sicken our conscience; their children run amuck; and their girls go bad.

Most of these problems, however, though identified with urban America, are not unique to this growing sector of society. It is patently impractical, undesirable, and almost meaningless in a complex society undergoing rapid and widespread change to separate the city, with its problems and prospects, from the larger society. Cities today are part-societies where everyday activities are linked to greater polities, economics, and extended networks of kin and friend. Much current discussion of urban affairs nevertheless treats this portion of society without reference to the whole. It is a curious abstraction to view both social order and its concomitant problems within the community as static or discrete, since all activities in an urban society are interwoven to form a large fabric whose pattern, like an "op" painting, constantly vibrates, restructures, moves unceasingly, and never settles down. The fascination of urban sociology lies in defining and understanding this constantly changing organization of thousands of disparate yet widely interdependent acts performed daily by all the people of the city and all those linked to it by interdependence or interaction. A profoundly important perspective may be thus gained for evaluating, formulating, and implementing enlightened public policy.

Such a perspective is not easy to acquire. No neat theory of urban social organization exists today even though the current renascence in urban studies and its attendant affluence has greatly increased research, writing, and systematic thinking in this area. What is being formed, instead, are sets of related ideas which are grounded in careful observations and which hang together well enough to be termed theoretical frames of reference. Basically, the framework for analysis of urban problems and prospects which is used here relates broad changes occurring in the larger society to the activities and opportunities of people settled in local areas of the city. This patterned sifting and sorting of people into local areas is part of the present transformation of urban communities, and a source of many current difficulties.

Of the several recent and significant influences, industrialization and urbanization are the two major changes most instrumental in transforming society through healing

- Ph.D. 1958, Yale University. Assistant Professor of Sociology, and Research Director, The Center for Metropolitan Studies, Northwestern University. 
or eliminating old divisions within it and yielding new ones. Industrialization has destroyed the traditional skill hierarchy, supplanting a set of distinctions based on an equation of age and seniority with skill, and substituting for it a new hierarchical division topped, for the moment, by those who possess highly specific technical skills. This current division apparently operates in all advanced industrial countries. ${ }^{1}$

An additional and serendipitous result of the new industrialization is the greatly diminished relevance of sex as a basis for limiting access to resources and rewards in the community. Recent expansion of the tertiary sector of industries and the dramatic enlargement in size and scale of many enterprises has widened the opportunity for gainful employment of women outside the household. It has yielded thereby a viable alternative to a style of life which centered on household, children, family, and kin. This new division, moreover, stemming from changes in the mode and scale of production, does not rest on the possession of certain types of skills but rather on opting one style of life over another. The distinction here, therefore, is between "urbanism" as characterized by small families and women working; and "familism," a life style associated with larger families and women at home."

As Durkheim, among others, points out, the process of industrialization thus erases older distinctions based on an age-graded, sex-selective division of labor. ${ }^{3}$ These older, ascriptive molds for the allocation of tasks and resources fall into disrepute only to be replaced by other sets of constraints, based on achieved skills and the exercise of a choice of life style. The newer constraints are buttressed by and defended in terms of the prevailing morality of "a career open to talents" and "the maximization of personal choice."

Viewed simply as the process of concentrating a large proportion of the population in a relatively few locations, urbanization inevitably produces new divisions within the community. The spatial consolidation of peoples destroys the internal homogeneity of the community because, in effect, it can be accomplished only by a major spatial redistribution of the population. This redistributive process yields two analytically distinct divisions within the urban community.

The first may be termed "migration status" and is based upon the extent to which movement from a place of origin to an urban center represents a movement across important social boundaries. Thus the experience of Whyte's organization man in going from one suburb to another across the country is not a movement over social boundaries. Whyte's organization man is not a stranger to the suburb: he is merely

\footnotetext{
${ }^{1}$ See Semore Martin Lipset \& Reinhard Bendix, Social Mobility in Industrial Society (I959); Neil J. SMelser, The Sociology of Economic Life ( $\mathrm{rg}_{3}$ ); and Wilbert E. Moore \& Bert F. Hoselitz (EDs.), INDUSTRIALIZATION AND SocietY (in collaboration with UNESCO) (1963), for general discussions of this process and significant consequences.

${ }^{2}$ See Eshref Shevky \& Marilyn Williaxis, The Social Areas of Los Angeles (1949); and Eshref Shevky \& Wendelx Bell, Social Area Analysis: Theory, Illustrative Application and ComputaTIONAL Procedures (1955), for an insightful synopsis of this transformation.

${ }^{3}$ Emile Durkheim, The Division of Labor in Soctety cc. 3-8 (1949).
} 
an urban man on the move. On the other hand, a strip miner's migration from Appalachia to Chicago traverses fewer miles, yet it crosses a much wider social gap. The miner is a newcomer to the city, and his choices are constrained not merely by his redundant skills or an option to a particular style of life but also by the novelty and alienness of a complex urban world.

Ethnic heterogeneity within the urban community is another consequence of the redistribution of people associated with urbanization. To the extent that cities draw upon populations with different physical or cultural backgrounds their composition is altered; and the urban community is divided by social visibilities. ${ }^{4}$

Both migration status and ethnic status are byproducts of the current pattern of urbanization in America. In its present form, this pattern results in the accumulation of substantial urban populations, each with distinct migration experiences and a variety of social visibilities. Like the divisions engendered by industrialization, these divisions also operate so as to limit access of individuals to the resources and rewards of the community. Unlike the constraints based on acquired skills and choice of life style, however, limitations arising from these sources are not directly legitimized by the prevailing public morality. But their indirect support is revealed by a close scrutiny of the "melting pot" ideology which indicates a widespread acceptance of the view that inequity is just and legitimate as long as cultural pluralism and inappropriate ruralism persists. In addition, the continuing American dilemma in race relations exposes the persistence of an indirect buttressing of inequity based on physical visibility.

Urbanization and industrialization, then, yield four basic dimensions of social differentiation along which the rewards and resources of urban communities are distributed. In the city the range of opportunities available to an individual or family is subject to the multiple constraints of economic status (based on skills); family status (based on life style option); migration status (based on migration experience); and ethnic status (based on social visibility).

Allocation of resources in terms of each of these status dimensions is, to some extent, legitimized by prevailing norms. In addition, all four statuses act in concert to delimit the range of opportunities open to urbanites. This is especially applicable in the case of housing opportunities. A long list of studies conducted in cities and metropolitin areas throughout the United States attests to the fact that all of these dimensions operate both separately and in combination to structure the pattern of residential settlement in American cities. ${ }^{5}$ This accumulated evidence indicates

\footnotetext{
-W. L. Warner \& Leo Srole, The Social Systems of American Ethnic Groups (i945); Nathan Glazer and Daniel Patrick Moynihan, Beyond the Melting Pot: The Negroes, Puerto Ricans, Jews, Italians, and Irish in New York City (1963); Oscar Handlin, The Newcomers (1963).

${ }^{-}$Cf. WARNer \& SROLE, op. cit. supra note 4, and other volumes of the Yankee City series for careful observations on the role of migrancy, ethnicity and class on patterns of settlement completed some twenty years ago. Recent materials include: Beverly Duncan \& Philip Hauser, Housing a Metropolis-: Chicago (1960); Stanley Lieberson, Ethnic Patrerns in American Cities: À Cómparative Studuy Using Data from T'en Urban Centers (I963); Anderson \& Bean, The Sheviky-Bell Social Areas:
} 
that local areas contain distinctive types of populations occupying different constellations of statuses and, as a consequence, have markedly different needs, demands, information, facilities, and modes of action.

Sets of relatively discrete problems are associated with the operation of cach of these dimensions. Economic status distinguishes local area populations in terms of the prevalent level of skills and other resources. Thus when localities are arrayed along this dimension they vary in concomitant needs and demands associated with accupational and educational achievements. At the lower levels of economic status, where localities contain substantial proportions of unskilled and uneducated workers, most of these problems resolve into the absolute constriction of life chances arising from poverty and ignorance. At somewhat higher statuses, lack of specific skills, skill redundancy, precarious employment, and highly unstable and insecure career trajectories are major issues. Above this lie the worries of the middle class: a scattering of problems concerned with extended educational training prior to employment, early plateauing of career trajectories, all the insecurities of white collar employment, and prolonged retirement and widowhood.

Important differences in concerns are observed as well between local areas arranged by family status. In urban localities where most people dwell in apartments, where wives work, families are small, and where there are many single people either just beginning their careers or retired from them, there exists some concern for the maintenance and improvement of the urban ambient. Occasionally worry is expressed about maintaining safe public spaces or preserving lively neighborhoods. For the most part, the world of the urban man is a world of career and consumption not oriented to the locality, where personal problems have more to do with economic status, ethnicity, and migrancy than with life style. The public problems of these

Confirmation of Results and a Reinterpretation, 40 Social ForCes 119 (1961); Anderson \& Egeland, Spatial Aspects of Social Area Analysis, 26 Am. Socıo. Rev. 392 (I96r); Bell, The Social Areas of the San Francisco Bay Region, 8 AM. Socro. Rev. 39 (1953); Bell, Economic, Family, and Ethnic Statts: An Empirical Test, 20 Am. Socro. Rev. 45 (1955); Bell, The Utility of the Shevly Typology for the Design of Urban Subarea Field Studies, 47 J. Soc. Psx. 71-83 (1958); Bell, Social Areas: Typology of Urban Neighborhoods, in Marvin Sussman (ED.), Community Structure and ANalysis (1959); Joun C. Bollens, Explaining the Metropolitan Community (r96r); Goldstein \& Mayer, Population Decline and the Social and Demographic Structure of an American City, 29 AM. Socio. Rev. 48 (1964), Grecr, Urbanism Reconsidered, 2 I AM. Socio. Rev. I9 (1956); Kahl, A Comparison of Indexes of Socio. Economic Status, 20 AM. Socro. Rev. 317 (I955); Walter C. Kaufman, A Factor-Analytic Test of Revisions in the Shevky-Bell Typology for Chicago and San Francisco, 1950 (unpublished Ph.D. thesis in Northwestern University Library, 196r); McElrath, The Social Areas of Rone: A Comparative Analysis, 27 Axr. Socto. Rev. 376 ( 1962 ); Mack \& McElrath, Urban Social Differentiation and the Allocation of Resources, 352 AnNals 25-32 (1964); Schmid, MacCannell \& Van Arsdol, Jr., The Ecology of the American City: Further Comparison and Validation of Generalizations, 23 AM. Socio. Rev. 392 (1958); Robert C. Tryon, Identification of Social Areas by Cluster Analysis (1955); Van Arsdol, Jr., Schmid \& Camilleri, A Deviant Case of Shevky's Dimensions of Urban Structure, Research Studies or the State College of Washincton (June 1957); Van Arsdol, Jr., Schmid \& Camilleri, The Generality of Urban Social Area Indexes, 23 AM. Socro. Rev. 277 (1958); Van Arsdol, Jr., Schmid \& Camilleri, An Application of the Shevky Social Area Indexes to a Model of Urban Society, 37 Social Fonces 26 (1958).

'CE. Bell, Social Choice, Life Styles and Suburban Residence, in William M. Donriner (ED.), Tui. Suburban Community 225-47 (x958). 
areas, however, are great. For the most part they revolve around decay and sterile renewal, a shrinking tax base, and the creation of a residential scene which perhaps only few people want and within which even the committed urbanite finds it difficult to persist. ${ }^{7}$

A quite different picture is observed, however, in familistic areas characterized by high fertility and women at home. Here, among the mortgaged single family dwellings of suburbia and in the familistic areas of the central city there exists a much greater concern for and involvement in the local area. Children blaze paths of interaction, bind local knots of interdependence, and magnify the importance of schools, neighborhood, and local community. In these areas current problems derive from the rearing of children and, often, the rapid, recent creation of vast horizontal neighborhoods. ${ }^{8}$

Ethnic status designates localities in terms of the presence of culturally and physically visible minorities. These areas are focal points associated with problems of shedding social visibilities and assimilation into the larger community. In the case of the culturally visible this process is generally a matter of three or four generations in America. With the physically visible, the rate of assimilation is appreciably slower, for their stigmata may be erased only through amalgamation or by defining the differences as socially meaningless in the acquisition of benefits of the community. This process, requiring dramatic normative and attitudinal changes is, to be sure, lengthy and its results often volatile. ${ }^{10}$

Finally, migration status identifies a set of local problems arising from the absence of urban skills and magnified by local reactions to newcomers. ${ }^{11}$ Historically, the difficulties which beset migrants were empirically and socially confused with ethnic status. It is now clear that the necessary skills, resources, and even motives for action in a large scale urban society are qualitatively distinct from the requirements of the little communities of the hinterland and foreland. The problems of the migrants arise from inappropriate responses to an urban world. Even when the experience of migration is less dramatic, constraints arise from the alienness of the new environment and the severing of old ties, modes of action, connections, and amenities. For migrants, then, basic problems involve the acquisition of urban skills and the establishment of new and meaningful relations with the alien community.

Each of these dimensions identifies sets of personal and social concerns which are problematic in our time. Only a few of these are isolated above; but even this listing indicates how the significance and relevance of urban problems systematically varies

\footnotetext{
${ }^{7}$ For a lively presentation of this polemic, see Jane Jacobs, The Death and Life of Great American Cities (196r); as well as The Enitors of Fortune, The Exploding Metropolis (196r).

${ }^{8}$ Sec especially Mowrer, The Family in Suburbia, in Dobriner, op. cit, supra note 6, at $147-64$, as well as several other chapters in this volume.

- Warner \& Srole, op. cit. supra note 4, and Lieberson, op. cit. supra note 5, are especially pertinent.

${ }^{10}$ See works cited supra note 4 .

21 lbid.
} 
from one locality in the city to another, in accordance with the relative standing of the population of each along four basic dimensions of social differentiation.

These are not isolated findings gleaned from occasional samples or a few scattered studies: the evidence is garnered from a large number of separate investigations which span the nation and several decades, and it is consistent evidence. From Providence to San Diego, all four dimensions differentiate between populations and define the problems of each. ${ }^{12}$ Within any community a greater understanding of the assets and activities of local area residents is gained by taking into account their standing along each of these dimensions and, more importantly, by considering the configuration of their standings. Their resources are limited not only by the prevalence of migrants, ethnics, an urban life style, or semi-skilled workers, but also by the combined influence of all of these limits.

This is critical to the present discussion because many of the enduring problems which presently plague cities arise from compounding inequity and constraint in localities within the community. Residents of an urban ghetto are disproportionately disadvantaged by the accumulation of limits stemming from low economic status, high levels of ethnicity, migrancy, and an urban life style. It is, however, not only a compounding of effects among the spatially isolated disadvantaged which is problem generating; difficulties also arise because these status dimensions are frequently crystallized among the advantaged as well.

The combined assets of localities which contain a high proportion of skilled, white, Protestant, long-term urbanites when conjoined with an option to familism usually involves an alignment with the amenities of suburbia. Not only does this result in the oft decried drainage of tax support from the central city but also in the removal of a significant sector of the population from a daily confrontation with the problems of the urban core. The highly disadvantaged who are entrapped in localities suffering from compounded deprivations thus become invisible to their opposites in suburbia. ${ }^{13}$ The compounding of extremes of deprivation on the one hand, and of advantage on the other, thus presents problems in addition to those which are directly associated with each dimension of differentiation.

Status crystallization at the extremes of each dimension, conjoined with residential segregation, is not, however, the usual condition in cities. Most localities beyond a minimum level of economic status vary widely in life style. Ethnicity and migrancy are often compounded in the extreme as, for example, in urban areas settled by Negroes from the rural South who are generally of low economic status. But this does not always obtain: "hillbillies" are unskilled, rural-to-urban migrants. However,

\footnotetext{
${ }^{12}$ Shevky \& Williams, op. cit. supra note 2; Shevky \& Bell, op. cit. supro note 2; and the last eighteen items of note 5 supra, are pertinent, along with several pieces in George A. Theodonson (Ed.), Studies in Human Ecology, esp. Part II (1961); Marvin B. Sussman (Ed.), Community Struc. ture and Analysis (r959); as well as the excellent discussion in Scott Greer, The Emerging City: MYTH AND REALITY (I962).

${ }^{13}$ Cf. Michael Harrington, The Other America: Poverty in the United States (ig62).
} 
they are not physically visible, while most Negroes in Chicago are visible; but these latter are often urban men-not migrants-and occasionally highly skilled. In fact, in almost every city studied, it is not possible to predict accurately where a locality stands along any one continuum from a knowledge of its standing along another. Each of the four dimensions is, except possibly at the extremes, quite independent of all of the others. ${ }^{14}$ This independence of the different ways of distributing resources within the community means that each local area is characterized by a fairly distinct status profile and, in turn, by a particular constellation of relevant problems and concerns. This metropolitan mosaic contains few concerns which are shared by all segments of the community. What is highly problematic in one locality is viewed with passive disinterest in another across the tracks or out among the trees of suburbia. But now, by careful analysis of mass data, we can begin to isolate these different types of localities and mixtures of interests and perhaps even begin to mobilize personal and community resources in terms of their needs.

The community, however, is not static and the divisions which now separate localities are being altered by advancing industrialization and urbanization. If present trends continue, it is likely that several of these dimensions will cease to affect large segments of the community and, more importantly, that the range of variation of localities along each will shift radically. First, the general rise in economic status of most localities in metropolitan areas, as observed in the last two censuses, is considered likely to continue. This change has resulted in a general upward shift for most localities and a marked increase in the proportion of highly advantaged localities. But the proportion of highly disadvantaged localities at the lowest levels of economic status has not altered greatly.

It is difficult to tell at this time if this upward increase in the average economic status will continue to be accompanied by a widening of the range of inequity. Perhaps present efforts to raise the skills and education of the most disadvantaged will result in the upward progression of the average economic status, accompanied by a shrinking range of inequity or, at the least, a fairly constant range.

The proportion of familistic localities has increased in nearly all metropolitan areas each decade since 1940. In addition, it has been observed that this life style is by far the most prevalent in ( $\mathrm{I}$ ) those areas of the nation which have experienced the greatest growth (the Southwest and Far West); (2) those sections of all metropolitan areas which have experienced greatest growth (the suburbs and fringe areas); and (3) among those economic groupings which have most increased in status (upper and middle class). ${ }^{15}$ It is likely that, given this strong thrust, this style of life will continue to be chosen by an increasingly large proportion of the total society. Further, with increasing economic status, it is probable that urban life style, at least in its

\footnotetext{
21 Cf. the several articles by Van Arsdol and others, stupra note 5; and also Ralph Eltison, ThE INVISIBLE MAN (I952).

15 Dennis McElrath, The New Urbanization and Trip Generation [forthcoming].
} 
present form, will be increasingly limited to those entrapped in the central city and unable to move.

The extreme form of migration status-the result of a radical shift from peasant to urban life-is likely to disappear in the next few decades. This will be due to both a diminution in the rate of rural to urban migration (we are running out of farmers) and the continued extension of urban forms throughout America and the continued increase in the intensity of involvement of all people in urban life. This long-term trend in the urbanization of American society is not likely to cease. Less extreme forms of migration status associated with movement that does not cross steep social boundaries will, however, probably persist since there is no evidence that the rate of long distance or short distance residential movement is likely to diminish. Changes in communications technology may, however, alter the social significance of this movement.

Proximate changes in ethnic status are difficult to assess in the light of recent changes in immigration policies which will affect the volume of immigration and the distribution of physical and cultural visibilities, as well as the distribution of skills among immigrants. Recent fluctuations in the migration patterns of Puerto Ricans also make projections with respect to this large minority difficult. Finally, current changes in norms and attitudes surrounding race relations will have a profound effect on the relevance of physical visibility to the distribution of resources within the community and concomitant problems. It is likely, however, that Negroes will continue to migrate to the urban North and West; that they will suffer inequities based on race alone; and that in many instances these will be compounded with disadvantages which stem from migrancy and low economic status.

In sum, the twin processes of urbanization and industrialization have yielded a fourfold division within the urban community. Each of these separately and in concert produce many current problems. The future course of these processes may heal some divisions and, possibly, bring about new ones. 